\title{
MAGNESIAN BORATES AND ASSOCIATED MINERALS IN THE CACOVA IERII SKARN DEPOSIT (APUSENI MOUNTAINS, ROMANIA)
}

\author{
Stefan Marincea*
}

\begin{abstract}
RESUMO
São apresentados estudos paragenéticos, de química mineral e propriedades físicas dos principais minerais do depósito de skarn magnesiano rico em boro de Cacova Ierii, Romênia. Comparados com minerais de depósitos similares da Romênia (e.g., Masca-Baisoara ou Ocna Fier), os minerais de Cacova mostram-se empobrecidos em manganês. Dados analíticos evidenciam pouca substituição de $\mathrm{Mn}$ por $\mathrm{Mg}$, mas significativa substituição de Fe por Mg. As variações mais consistentes de composição envolvem as relações Fe/Mg, na comparação dos boratos de $\mathrm{Mg}$ com os silicatos e óxidos coexistentes. A geotermometria dos carbonatos permite estimativas da temperatura de cristalização entre $300^{\circ}$ e $580^{\circ} \mathrm{C}$, em acordo com as experiências de síntese.
\end{abstract}

\section{INTRODUCTION}

Skarn-related boron deposits are ubiquitous in the earth crust: worldwide, about 80 such deposits were inventoried by Aleksandrov (1982). As observed by Pertsev (1991), such boron mineralizations are one of the most common types of ore deposits related to magnesian skarns. They are generally associated to the postmagmatic processes which occur in the contact areas of intrusive, acid to intermediary, calc-alkaline rocks. In Romania, deposits of this type have been reported from magnesian skarns at a number of localities i.e., Ocna de Fier (the type locality of ludwigite), Pietroasa, Masca-Baisoara, Baita Bihor (the type locality of szaibelyite) and Cacova Ierii (Marincea, 1998). Note that all the quoted occurrences are typically related to metasomatic areas developed around calcalkaline intrusive bodies of Late Cretaceous - Paleogene age, which are called by the collective term "banatites", firstly used by von Cotta (1864).

Known for over two decades, the occurrence at Cacova Ierii hosts one of the most characteristic skarnrelated boron deposits in Romania. Previous studies by Marincea \& Cristea (1995) and Marincea (1997) offered preliminary data on the mineralogy of this deposit. The purpose of this paper is to give a full image on the parageneses, mineral chemistry, reciprocal relationships and physical properties of the main mineral species from the boron-bearing magnesian skarns from Cacova Ierii.

\section{GEOLOGICAL SETTING}

Geographically, the Cacova Ierii skarn complex is located in Gilau Massif, in the eastern part of the
Apuseni Mountains, approximately $27 \mathrm{~km}$ south southwest of Cluj, which is the major city in this area. The skarn area is developped at the very contact of a small-sized hypabissal granodioritic body which intrudes basement rocks of the Baia de Aries Group, of Proterozoic age (Iancu \& Balintoni, 1986), and of the Vulturese-Belioara Group, of Carboniferous age (Hârtopanu et al., 1982). In general, such magmatic bodies are referred to by the collective term "banatite", after von Cotta (1864), who first described at locus tipicus - Banat, a consanguineous series of compositionally intermediate intrusive rocks of Late Cretaceous - Paleogene age. Between the Northern Apuseni Mountains in Romania, through Timok in Yugoslavia to Srednogorie and Black Sea coast in Bulgaria, magmatites of this age, which display a mainly calk-alkaline affinity, define a discontinuous belt (the "banatitic magmatic and metallogenetic belt" according to Berza et al., 1998) with a significant associated metallogenesis (e.g., Jankovic, 1997; Berza et al., 1998; Popov et al., 2000). A geological sketch of the Cacova Ierii area, showing its position within the banatitic belt, is given in Figure 1.

In the study area, the banatitic bodies and the related skarns crop out discontinuously over an area of about 8 $\mathrm{km}^{2}$, between Masca-Baisoara and Cacova Ierii. The exact radiometric age of these bodies is unknown, but they are potentially correlative with the second intrusive event of the "banatitic" magmatism in the Apuseni area (Danian - Ypresian in age according to Stefan et al., 1988).

Skarns from Cacova Ierii occupy large zones within the contact area. They characteristically form metasomatic columns whose outer zones are usually composed by magnesian, sometimes boron-bearing, skarns, whereas the inner zone consists of calcic skarns, 


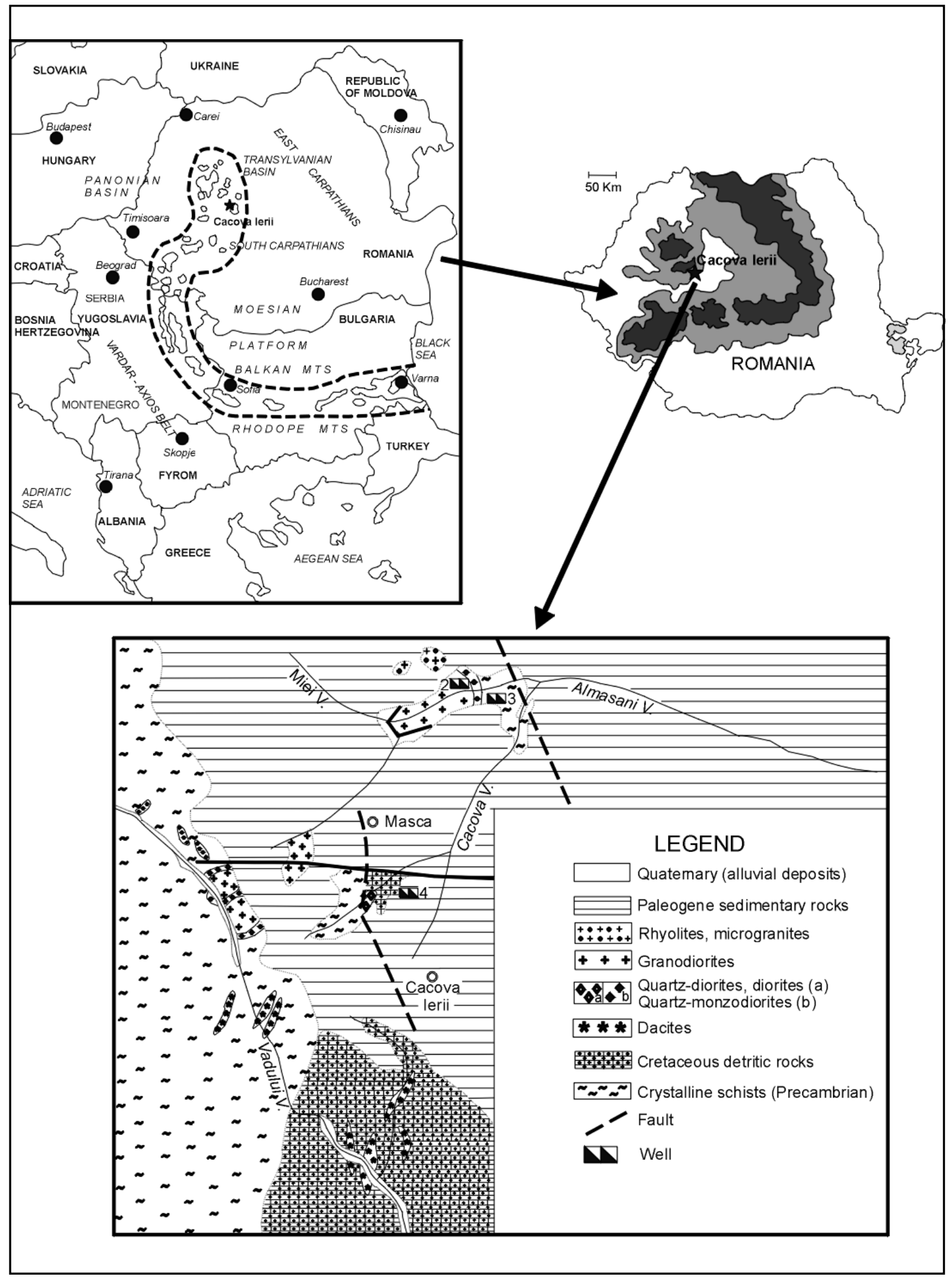

Figure 1. Location and geological sketch of the Cacova Ierii area (redrawn from Lazar et al., 1975, unpublished). The extension of the banatitic belt as given by Berza (1998).

Figura 1. Localização e esboço geológico da área Cacova Ierii (modificado de Lazar et al., 1975, inédito). Extensão do Banatitic Belt segundo Berza (1998). 
containing andradite and diopside. Beside borates (ludwigite and kotoite), the primary paragenesis of magnesian skarns comprises dolomite, calcite, magnesite, forsterite, clinohumite and chondrodite. Secondary parageneses, including szaibelyite, brucite, chrysotile, lizardite, clinochlore, pyroaurite, lepidocrocite, goethite, pyrite, pyrrhotite, arsenopyrite, chalcopyrite, sphalerite, galena, marcassite and covellite overlap on the primary ones. Because only few of these mineral species show paragenetic relations with the boron minerals, only these ones will be investigated below.

\section{PRIMARY MINERALS}

Calcite represents the main carbonate phase in the boron-bearing skarns. The mineral is coarse-grained and sometimes forms patches around $\mathrm{Mg}$-silicates, borates or brucite. Mean chemical compositions of representative samples of carbonates from Cacova Ierii, including calcite, are given in Table 1.

As may be deduced from this table, the mineral is $\mathrm{Fe}$ - and Mn-depleted, which suggests that at Cacova Ierii calcite occurred as a result of a process similar to these involved in the genesis of "magnesium-free" marbles, during the thermal metamorphism.

Dolomite in the boron-bearing skarns occurs both as large patches of medium-grained crystals, associated with calcite and magnesite, and as linear segregations disposed along the calcite perfect cleavage after $(10 \overline{1} 1)$, in angular unconformity with the polysynthetic twinning. In the first case, the mineral is the main constituent of some unmetasomatized remnants of dolomitic marbles, whereas in the second it represents the product of an exsolutive process, induced by the thermal reequilibration. As is suggested by the representative analyses in Table 1, the magnesian dolomite $(\mathrm{Mg}>\mathrm{Ca})$ predominate over the calcian one $(\mathrm{Mg}<\mathrm{Ca})$, which accounts for the consumption of $\mathrm{Mg}$ during the crystallization of $\mathrm{Mg}$ silicates and borates.

\begin{tabular}{|c|c|c|c|c|c|c|c|c|c|}
\hline Sample & 1819 & 2140 & 2199 & 1466 & 1821 & 2199 & 2194 & 2198 & 2222 \\
\hline Mineral $^{(1)}$ & cal & cal & cal & dol & dol & dol & mgs & mgs & mgs \\
\hline $\mathrm{N}^{(2)}$ & 9 & 3 & 4 & 4 & 3 & 4 & 3 & 3 & 3 \\
\hline $\mathrm{CaO}$ & 53.631 & 52.517 & 54.408 & 28.342 & 30.087 & 31.284 & 0.009 & 0.116 & 1.293 \\
\hline $\mathrm{MgO}$ & 1.836 & 2.561 & 1.257 & 21.602 & 21.781 & 20.699 & 46.188 & 45.816 & 46.214 \\
\hline $\mathrm{FeO}^{(3)}$ & 0.185 & 0.423 & 0.083 & 2.524 & 0.318 & 0.342 & 2.052 & 2.377 & 0.233 \\
\hline $\mathrm{MnO}$ & 0.087 & 0.142 & 0.081 & 0.096 & 0.138 & 0.193 & 0.032 & 0.071 & 0.395 \\
\hline $\mathrm{CO}_{2}^{(4)}$ & 44.261 & 44.357 & 44.171 & 47.436 & 47.676 & 47.482 & 51.719 & 51.620 & 51.865 \\
\hline \multicolumn{10}{|c|}{ Number of ions on the basis of 6 oxygen anions } \\
\hline $\mathrm{Ca}^{2+}$ & 1.902 & 1.858 & 1.934 & 0.938 & 0.990 & 1.034 & 0.000 & 0.004 & 0.039 \\
\hline $\mathrm{Mg}^{2+}$ & 0.091 & 0.126 & 0.062 & 0.994 & 0.998 & 0.952 & 1.950 & 1.938 & 1.947 \\
\hline $\mathrm{Fe}^{2+}$ & 0.005 & 0.012 & 0.002 & 0.065 & 0.008 & 0.009 & 0.049 & 0.056 & 0.005 \\
\hline $\mathrm{Mn}^{2+}$ & 0.002 & 0.004 & 0.002 & 0.003 & 0.004 & 0.005 & 0.001 & 0.002 & 0.009 \\
\hline$\left(\mathrm{CO}_{3}\right)^{2-}$ & 2.000 & 2.000 & 2.000 & 2.000 & 2.000 & 2.000 & 2.000 & 2.000 & 2.000 \\
\hline \multicolumn{10}{|c|}{ Composition in end-members (mol.\%) } \\
\hline calcite & 95.10 & 92.90 & 96.70 & 46.90 & 49.50 & 51.70 & 0.00 & 0.20 & 1.95 \\
\hline magnesite & 4.55 & 6.30 & 3.10 & 49.70 & 49.90 & 47.60 & 97.50 & 96.90 & 97.35 \\
\hline siderite & 0.25 & 0.60 & 0.10 & 3.25 & 0.40 & 0.45 & 2.45 & 2.80 & 0.25 \\
\hline rhodochros & site 0.10 & 0.20 & 0.10 & 0.15 & 0.20 & 0.25 & 0.05 & 0.10 & 0.45 \\
\hline
\end{tabular}

(1) - cal = calcite; dol = dolomite; mgs = magnesite; (2) - number of point analyses; (3) - total iron as FeO;

(4) - as calculated for stoichiometry, with totals recalculated at $100 \%$.

Table 1. Electron-microprobe analyses of selected samples of carbonates from Cacova Ierii.

Tabela I. Análises de microsonda de alguns carbonatos de Cacova Ierii.

Magnesite was generally found as pseudomorphs on brucite, which probably represents the result of the high activity of $\mathrm{CO}_{2}$ induced by the breakdown of dolomite during the boron metasomatism. The representative compositions reported in Table 1 are characteristic for terms very close to the magnetite endmember. The unit-cell parameters calculated for a representative sample (least squares on $24 \mathrm{X}$-ray powder reflections) are $a=4.635(1) \AA$ and $b=$ 14.994(2) A, which agrees with the chemical data.

Forsterite occurs as disseminated crystals or more commonly in irregular aggregates of euhedral or subhedral crystals, enclosed by the ludwigite mass. The mineral is commonly rimmed, or partly replaced, by serpentine (mainly chrysotile) \pm brucite.

Optically, forsterite from Cacova Ierii is biaxial positive. The high $2 \mathrm{~V}$ angles $\left(+2 \mathrm{~V}=86-88^{\circ}\right)$, indicate nearby stoichiometric terms. Cell parameters $(a=4.750$ - 4.756 $\AA, b=10.199-10.210 \AA, c=5.983-5.987 \AA$ ) account for low contents of fayalite in solid solution. Based on the equations of Jahanbagloo (1969), contents of forsterite in solid solution higher than $93.78 \mathrm{~mol} . \%$ 
may be estimated. These estimations are in very good agreement with the selected chemical compositions listed in Table 2, which indicate very low contents of tephroite and variable, but low, contents of fayalite in solid solution: $0.15-0.86 \mathrm{~mol} \%$ and $1.78-5.22 \mathrm{~mol} . \%$ respectively. As may be observed in Figure 2 (left), the plots of representative compositions of forsterite from Cacova Ierii in a ternary $\mathrm{Mg}-\mathrm{Fe}^{2+}-\mathrm{Mn}$ diagram trend to be disposed along a direction that parallels the join forsterite - fayalite, at low contents of tephroite.
Magnetite may form monomineralic bands of optically unzoned grains or occur as isolated grains, which are interstitial to silicates (i.e., forsterite, clinohumite) or to ludwigite. Paragenetic relations between borates and spinel indicate two generations of magnetite, in equilibrium with ludwigite and szaibelyite respectively. The cell parameters, calculated for nine different samples by least squares, using 12 to 17 unambiguously indexed $\mathrm{X}$-ray powder reflections in the $2 \mathrm{q}$ range of 10 to $100^{\circ}$, vary between $8.371(4)$ and

\begin{tabular}{|c|c|c|c|c|c|c|c|c|c|}
\hline Sample & 1835 & 2140 & 2200 & 1818 & 2199 & 2198 & 1835 & 2223 & 2199 \\
\hline Mineral $^{(1)}$ & fo & fo & fo & chu & chu & cho & chr & chr & liz \\
\hline No. ${ }^{(2)}$ & 5 & 7 & 4 & 7 & 5 & 5 & 8 & 3 & 2 \\
\hline $\mathrm{SiO}$ & 42.881 & 41.691 & 41.301 & 38.011 & 37.214 & 31.448 & 38.938 & 38.947 & 39.854 \\
\hline $\mathrm{TiO}^{2}$ & 0.014 & 0.000 & 0.066 & 0.019 & 0.000 & 0.117 & - & - & - \\
\hline $\mathrm{Al} O \tilde{O}$ & 0.000 & 0.000 & 0.000 & 0.000 & 0.000 & 0.006 & 0.077 & 0.045 & 0.072 \\
\hline $\mathrm{BO}^{3}$ & - & - & - & - & - & 2.600 & 0.090 & 1.233 & 0.728 \\
\hline $\mathrm{FeO}^{2} \mathrm{\beta}^{(3)}$ & 1.769 & 2.000 & 5.223 & 0.450 & 2.227 & 0.604 & 2.808 & 4.902 & 2.805 \\
\hline $\mathrm{MgO}$ & 54.457 & 56.126 & 53.059 & 56.675 & 54.864 & 58.291 & 40.124 & 40.392 & 39.58 \\
\hline $\mathrm{MnO}$ & 0.838 & 0.149 & 0.334 & 0.454 & 0.213 & 0.198 & 0.116 & 0.013 & 0.044 \\
\hline $\mathrm{CaO}$ & 0.041 & 0.034 & 0.017 & 0.092 & 0.187 & 0.007 & 0.025 & 0.022 & 0.073 \\
\hline $\mathrm{F}$ & - & - & - & 2.083 & 3.036 & 0.038 & - & - & - \\
\hline $\mathrm{H} \mathrm{O}^{(4)}$ & - & - & - & 1.881 & 1.332 & 4.816 & - & - & - \\
\hline Tôtal & 100.000 & 100.000 & 100.000 & 99.665 & 99.073 & 98.125 & 82.178 & 85.554 & 83.156 \\
\hline \multicolumn{10}{|c|}{ Cations on the basis of $\mathrm{N}^{(5)}(\mathrm{O})$} \\
\hline $\mathrm{Si}^{4+}$ & 1.014 & 0.987 & 0.992 & 4.005 & 3.991 & 1.781 & 3.879 & 3.747 & 3.897 \\
\hline $\mathrm{Ti}^{4+}$ & 0.000 & 0.000 & 0.001 & 0.002 & 0.000 & 0.005 & - & - & - \\
\hline $\mathrm{Al}^{3+}$ & 0.000 & 0.000 & 0.000 & 0.000 & 0.000 & 0.000 & 0.009 & 0.005 & 0.008 \\
\hline $\mathrm{B}^{3+}$ & - & - & - & - & - & 0.254 & 0.015 & 0.205 & 0.123 \\
\hline $\mathrm{Fe}^{2+}$ & 0.035 & 0.040 & 0.105 & 0.040 & 0.200 & 0.029 & 0.234 & 0.394 & 0.229 \\
\hline $\mathrm{Mg}^{2+}$ & 1.919 & 1.982 & 1.901 & 8.903 & 8.769 & 4.921 & 5.959 & 5.793 & 5.769 \\
\hline $\mathrm{Mn}^{2+}$ & 0.017 & 0.003 & 0.007 & 0.041 & 0.019 & 0.009 & 0.010 & 0.001 & 0.004 \\
\hline $\mathrm{Ca}^{2+}$ & 0.001 & 0.001 & 0.001 & 0.010 & 0.021 & 0.000 & 0.003 & 0.002 & 0.008 \\
\hline $\mathrm{F}^{-}$ & - & - & - & 0.694 & 1.029 & 0.007 & - & - & - \\
\hline $\mathrm{OH}^{-}$ & - & - & - & 1.322 & 0.953 & 1.819 & - & - & - \\
\hline
\end{tabular}

(1) - fo = forsterite; chu = clinohumite; cho = chondrodite; chr = chrysotile; liz = lizardite; (2) - number of point analyses; (3) - total $\mathrm{Fe}$ as $\mathrm{FeO}$; (4) - $\mathrm{H}$ O calculated for stoichiometry in clinohumite and chondrodite; (5) - $\mathrm{N}=$ number of $(\mathrm{O}, \mathrm{OH}, \mathrm{F})$ atoms $\left[4\left(\mathrm{O}^{2}\right)\right.$ in forsterite; $14(\mathrm{O})$ in chrysotile and lizardite; $16(\mathrm{O})$ and 13 cations in clinohumite; $8(\mathrm{O})$ and 7 cations in chondrodite].

Table 2. Electron-microprobe analyses of selected samples of silicates from Cacova Ierii.

Tabela 2. Análises de microsonda eletrônica de alguns silicatos de Cacova Ierii.

8.400 (2) $\AA$. These values remain close by that one given by Basta (1957) for the stoichiometric magnetite ( $a=$ $8.396 \AA$ ), but suggest chemical variability of the analyzed samples. Electron-microprobe analyses of samples of magnetite I (in equilibrium with ludwigite) confirms this assumption. After recalculation on the basis of 24 cations and $32(\mathrm{O})$ of the structural formulae and the corresponding partition of iron between the sixfold and the four-fold coordinated sites, it results that the major chemical variability is due to the isomorphism in the magnetite - magnesioferrite series. Between 8.61 and 37.80 mol.\% magnesioferrite were deduced, in conditions of low contents of jacobsite (up to 3.89 mol.\%), ulvöspinel (up to $0.38 \mathrm{~mol} . \%$ ) and spinel hercynite (up to $1.67 \mathrm{~mol} \%$ ). In fact, as may be seen in Figure 2 (right), the trend of magnetite plots to align along the join magnetite - magnesioferrite parallels that of forsterite. Note that between two and nine point analyses on magnetite $\mathrm{I}$ in the same thin section were averaged to yield each composition plotted in Figure 2 .

Ludwigite is the most abundant borate in the magnesian skarns at Cacova Ierii. The mineral occurs as needle-like, fibrous or prismatic crystals, up to 4.5 

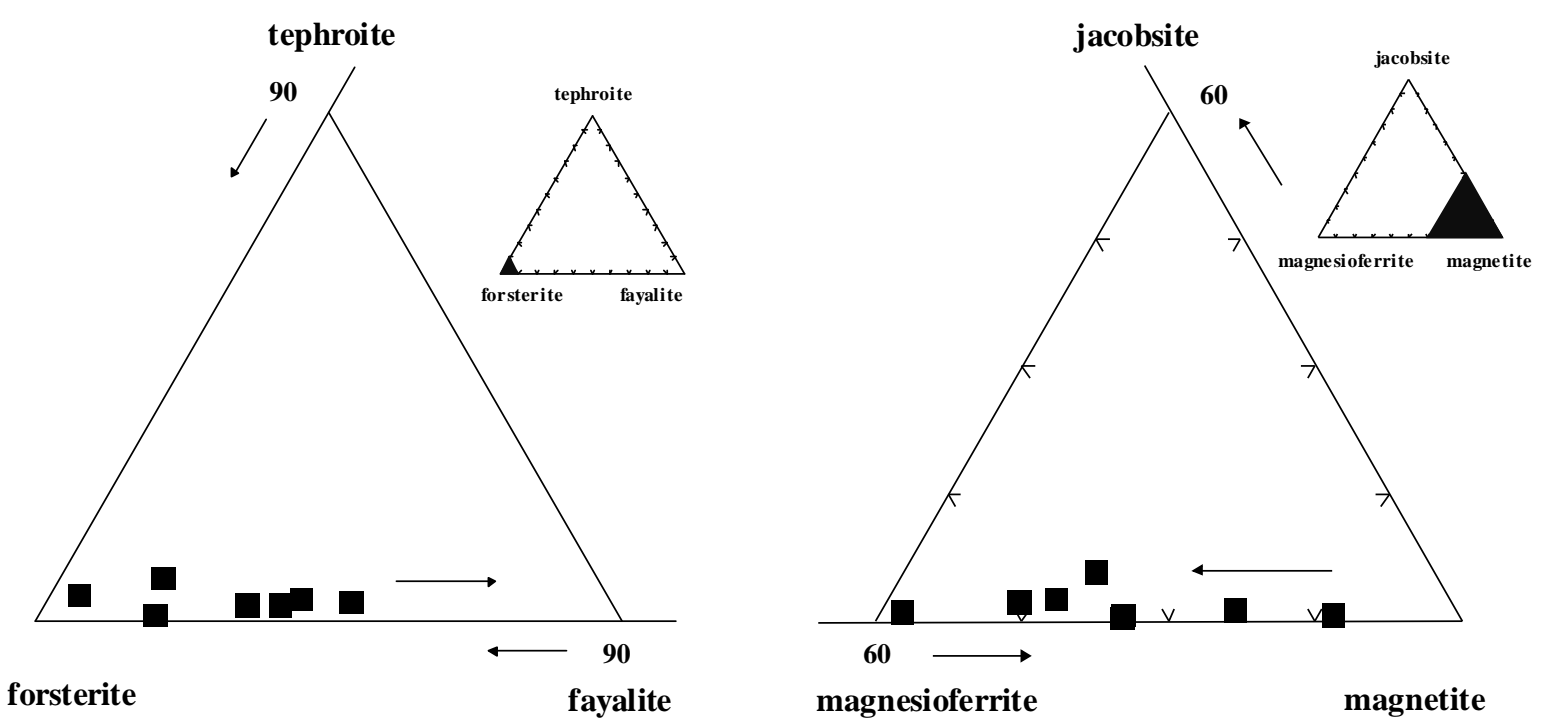

Figure 2. Isomorphism between $\mathrm{Mg}$-, $\mathrm{Fe}$ - and $\mathrm{Mn}$-end-members in forsterite (left) and magnetite (right) from Cacova Ierii boron-bearing skarns.

Figure 2. Isomorfismo entre $\mathrm{Mg}$-, Fe- e Mn em forsterita (esquerda) e magnetita (direita) de skarns contendo boro de Cacova Ierii.

$\mathrm{cm}$ in length, generally grouped in fan-shaped or radiating aggregates. These aggregates usually defines layers or bands alternating with magnetite, which reach a few $\mathrm{mm}$ to $5 \mathrm{~cm}$ in thickness. Ludwigite from Cacova Ierii has a variable content of vonsenite in solid solution (4.91 to $25.95 \mathrm{~mol} . \%$ ) and is Al- and Ti-poor (containing up to $9.10 \mathrm{~mol} \% \mathrm{Mg}_{2} \mathrm{Al}\left(\mathrm{BO}_{3}\right) \mathrm{O}_{2}$ and $0.70 \mathrm{~mol} . \%$ azoproite). The low contents in Mn (up to 0.54 wt.\% $\mathrm{MnO}$ ) and $\mathrm{Ni}$ (up to $14 \mathrm{ppm}$ ) show that the isomorphism in the ludwigite - fredrikssonite and ludwigite bonaccordite series is negligible. Representative chemical compositions are given in Table 3 . The variability of both cell parameters $[a=9.210(9)$ -

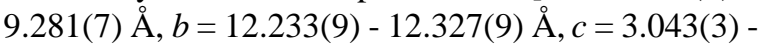
3.059(2) $\AA$ ] and of physical ones (i.e., $D_{\mathrm{x}}=3.796-3.987$ $\left.\mathrm{g} / \mathrm{cm}^{3} ; \bar{n}_{\text {Gladstone-Dale }}=1.946-1.985\right)$ accounts for extensive $\mathrm{Fe}^{2+}$-for-Mg substitutions.

Kotoite occurs as anhedral to subhedral grains that form the centers of mesh-textures of szaibelyite. SEM and electron-microprobe study of several aggregates show that individual grains are characteristic overcoated by thin crusts of brucite. The unit-cell parameters, refined by least squares for five sets of 31 to $32 \mathrm{X}$-ray powder reflections for which unambiguous assumption was possible, are $a=5.935(2)-5.408(5) \AA, b=8.409(4)$ 8.430(10) $\AA$ and $c=4.505(3)$ - 4.507(4) $\AA$. Representative compositions, as given by electronmicroprobe analysis, are given in Table 3 . The compositions in end-members of a larger set of samples indicate that $\mathrm{Fe}_{3}\left(\mathrm{BO}_{3}\right)_{2}(1.53-2.11 \mathrm{~mol} . \%)$ always prevails over the jimboite $(0.14-0.23 \mathrm{~mol} . \%)$ and takedaite (0.00 - $0.06 \mathrm{~mol} \%)$ components. As may be seen in Figure 3 (left), the trend toward the $\mathrm{Fe}_{3}\left(\mathrm{BO}_{3}\right)_{2}$ end-member is clearly manifested in the disposition of the plots of the analyzed samples.
Clinohumite and chondrodite in the borate-bearing skarns occur most commonly as discrete subhedral grains in the matrix of ludwigite and magnetite. A thin seam of chrysotile \pm brucite surrounds most of the grains. Selected microprobe analyses of both minerals are given in Table 2. As a characteristic feature, they are fluorine-poor (the average $\mathrm{X}_{\mathrm{F}}=\mathrm{F} /(\mathrm{F}+\mathrm{OH})=0.42$ for clinohumite and 0.04 for chondrodite respectively). Both minerals are also Mn-poor: averages of 0.21 mol.\% sonolite and $0.18 \mathrm{~mol} \%$ alleghanyite respectively may be deduced on the basis of microprobe analyses. As may be observed in Table 2, chondrodite from Cacova Ierii contains a substantial amount of boron, which was undetected in clinohumite.

\section{SECONDARY MINERALS}

Szaibelyite occurs as bunches of small needle-like crystals, near the limits of optical resolution. It always forms polycrystalline pseudomorphs on ludwigite. Symplectitic intergrowths with strings of magnetite II may be observed at the periphery of some ludwigite crystals. The mean cell parameters, deduced by leastsquares refinement of eight sets of X-ray powder data, are $a=12.562(21), b=10.394(19), c=3.135(8) \AA$ and $\mathrm{b}=95.51(51)^{\circ}$.

The mineral contains only 0.15 to $0.35 \mathrm{~mol} \%$ sussexite in solid solution. The larger contents in the $\mathrm{Fe}_{2}\left(\mathrm{~B}_{2} \mathrm{O}_{4} \mathrm{OH}\right)(\mathrm{OH})$ component (an average of 2.34 mol.\%) define a main isomorphism in the szaibelyite $\mathrm{Fe}_{2}\left(\mathrm{~B}_{2} \mathrm{O}_{4} \mathrm{OH}\right)(\mathrm{OH})$ series. This is clearly shown by the representative analyses in Table 3 and by the ternary diagram in Figure 3 (right), which indicates that all the analyzed samples are characterized by a strong tendency toward the $\mathrm{Fe}_{2}\left(\mathrm{~B}_{2} \mathrm{O}_{4} \mathrm{OH}\right)(\mathrm{OH})$ end-member. 
(APUSENI MOUNTAINS, ROMANIA)

\begin{tabular}{|c|c|c|c|c|c|c|c|c|c|}
\hline Sample & 1300 & 1302 & 2196 & 2194 & 2198 & 2223 & 1466 & 1467 & 2194 \\
\hline Mineral & $\mathrm{lw}$ & $\mathrm{lw}$ & $\mathrm{lw}$ & ko & ko & ko & sz & $\mathrm{sz}$ & $\mathrm{sz}$ \\
\hline No. ${ }^{(2)}$ & 11 & 5 & 6 & 5 & 7 & 5 & 3 & 4 & 5 \\
\hline $\mathrm{B} \mathrm{O}$ & 16.339 & 16.751 & 17.527 & 35.445 & 35.660 & 36.116 & 41.078 & 40.769 & 40.251 \\
\hline $\mathrm{T}_{1}^{2} \mathrm{O}^{3}$ & 0.034 & 0.016 & 0.008 & - & - & - & - & - & - \\
\hline $\mathrm{Al} \mathrm{O}$ & 1.036 & 0.556 & 0.026 & - & - & - & 0.019 & 0.385 & 0.004 \\
\hline $\mathrm{Fe}^{2} \mathrm{O}^{3(3)}$ & 37.087 & 35.955 & 40.235 & - & - & - & - & - & - \\
\hline $\mathrm{FeO}^{(3)}$ & 17.214 & 17.893 & 3.561 & 1.701 & 2.326 & 1.774 & 0.791 & 2.396 & 2.460 \\
\hline $\mathrm{MgO}$ & 28.024 & 28.645 & 38.511 & 60.697 & 60.205 & 61.789 & 47.200 & 45.627 & 45.084 \\
\hline $\mathrm{MnO}$ & 0.234 & 0.157 & 0.114 & 0.228 & 0.179 & 0.240 & 0.198 & 0.134 & 0.239 \\
\hline $\mathrm{CaO}$ & 0.032 & 0.027 & 0.018 & 0.022 & 0.028 & 0.011 & 0.032 & 0.033 & 0.013 \\
\hline $\mathrm{H} \mathrm{O}^{(4)}$ & - & - & - & - & - & - & 10.794 & 10.678 & 10.417 \\
\hline $\mathrm{F}^{2}$ & - & - & - & - & - & - & 0.000 & 0.126 & 0.005 \\
\hline Total & 100.000 & 100.000 & 100.000 & 98.093 & 98.398 & 99.930 & 100.112 & 100.148 & 98.473 \\
\hline \multicolumn{10}{|c|}{ Cations on the basis of $\mathrm{N}^{(5)}(\mathrm{O})$} \\
\hline $\mathrm{B}^{3+}$ & 0.990 & 1.012 & 0.999 & 1.996 & 2.005 & 1.997 & 2.000 & 2.000 & 2.000 \\
\hline $\mathrm{Ti}^{4+}$ & 0.001 & 0.000 & 0.000 & - & - & - & - & - & - \\
\hline $\mathrm{Al}^{3+}$ & 0.043 & 0.023 & 0.001 & - & - & - & 0.001 & 0.013 & 0.000 \\
\hline $\mathrm{Fe}^{3+}$ & 980 & 947 & .000 & - & - & - & - & - & - \\
\hline $\mathrm{Fe}^{2+}$ & 0.505 & 0.524 & 0.098 & 0.046 & 0.063 & 0.048 & 0.019 & 0.057 & 0.059 \\
\hline $\mathrm{Mg}^{2+} \mathrm{H}-\mathrm{e}$ & 1.466 & 1.495 & 1.897 & 2.952 & 2.923 & 2.950 & 1.984 & 1.933 & 1.935 \\
\hline $\mathrm{Mn}^{2+}$ & 007 & 005 & 0.003 & 0.006 & 0.005 & 0.007 & 0.005 & 0.003 & 0.006 \\
\hline $\mathrm{Ca}^{2+}$ & 0.001 & 0.001 & 0.001 & 0.001 & 0.001 & 0.000 & 0.001 & 0.001 & 0.000 \\
\hline$(\mathrm{OH})^{-}$ & - & - & - & - & - & - & 2.021 & 2.017 & 2.000 \\
\hline $\mathrm{F}^{-}$ & 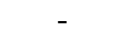 & - & 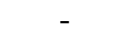 & 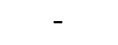 & - & - & 0.000 & 0.011 & 0.000 \\
\hline
\end{tabular}

(1) - lw = ludwigite; ko = kotoite; sz = szaibelyite; (2) - number of point analyses; (3) - total Fe as FeO for kotoite and szaibelyite. Fe O calculated for stoichiometry in ludwigite; (4) - in szaibelyite, $\mathrm{H} O$ calculated in order to fulfill the charge balance; (5) - $\mathrm{N}=$ number of oxygen atoms [5 (O) in ludwigite; $6(\mathrm{O})$ in kotoite; $4(\mathrm{O})$ and 2 boron atoms in szaibelyite].

Table 3. Electron-microprobe analyses of selected samples of borates from Cacova Ierii.

Tabela 3. Análises de microsonda eletrônica de algumas amostras de Cacova Ierii.
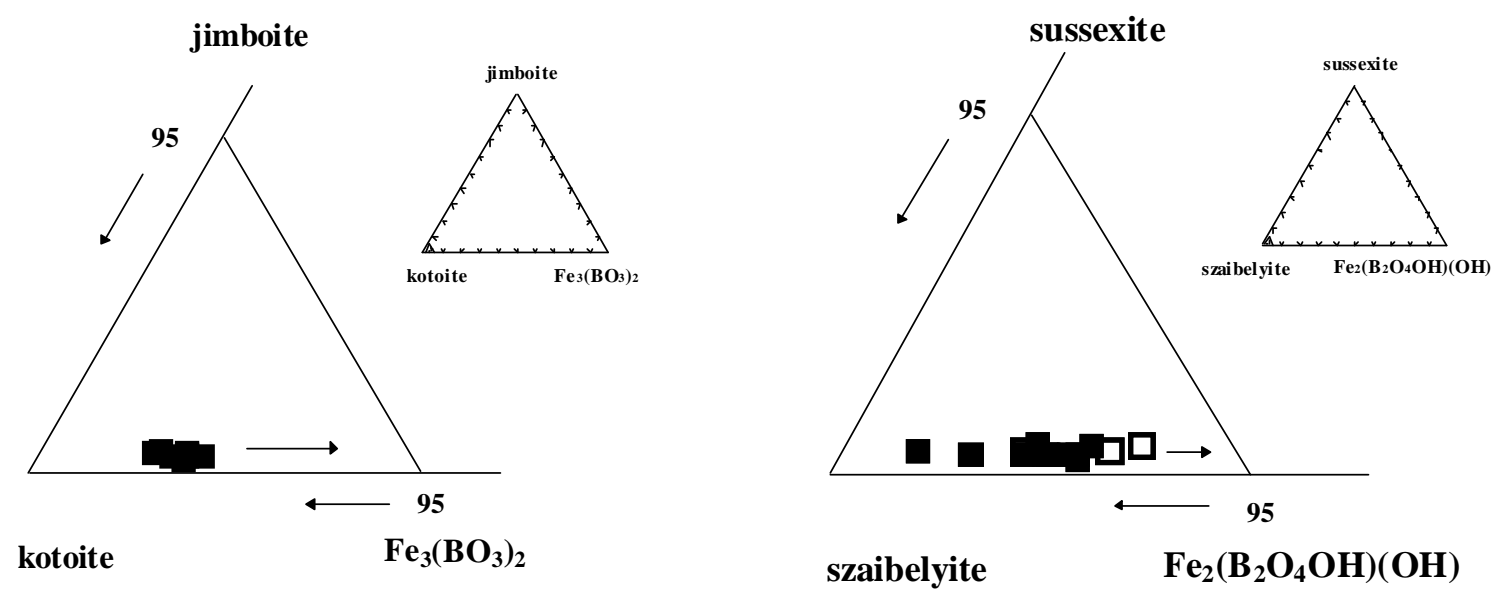

Figure 3. Isomorphism between $\mathrm{Mg}$-, $\mathrm{Mn}$ - and Fe-end-members in kotoite (left) and szaibelyite (right) from Cacova Ierii, as given by electron-microprobe (filled squares) and wet-chemical (wide squares) analyses.

Figure 3. Isomorfismo entre Mg-, Mn- and Fe em kotoita (esquerda) e szaibelyita (direita) de Cacova Ierii, segundo análises de microsonda eletrônica (quadrados cheios) e química via-úmidal (quadrados vazados). 
Lizardite and chrysotile typically occur as rims of forsterite or humites or, more commonly, in pseudomorphic mesh-textures after forsterite. The compositions of three representative samples are reported in Table 2 . They were carried out on vein chrysotile and on an mesh center consisting in lizardite $1 T$. Note that lizardite always contains significant amounts of B ( 0.123 to 0.247 a.p.f.u.), to be compared with only 0.000 to 0.010 a.p.f.u. B in chrysotile.

Brucite generally occurs in replacement aggregates on forsterite, clinohumite or ludwigite, but may also appear as thin coatings on kotoite or as coarse laths up to $0.5 \mathrm{~mm}$ across in the carbonate mass. In all cases, the mineral may be better described as a limited solid solution toward the amakinite end-member (2.40 to 2.90 mol.\%). Low fluorine concentrations (up to $1.3 \mathrm{~mol} . \%$ "sellaite" in solid solution) were found in the platy nonpseudomorph brucite in the carbonate mass. In contrast, no fluorine substitutes for hydroxyl groups in brucite that forms coatings on kotoite.

\section{CONCLUSIONS}

The boron-bearing magnesian skarn deposit from Cacova Ierii is one of the most representative in Romania. In comparison with minerals from other similar deposits in Romania (e.g., Masca-Baisoara or Ocna de Fier) the minerals from Cacova Ierii show Mndepleted compositions. Compositional data show, in all cases, very restricted $\mathrm{Mn}$-for-Mg substitution and visibly larger substitution of $\mathrm{Fe}$-for-Mg. The most consistent compositional variations involve the $\mathrm{Fe} / \mathrm{Mg}$ ratios. In this respect, the chemical compositions of $\mathrm{Mg}$ borates parallel those of the coexisting silicates and oxides.

The temperatures resulting from the application of the magnesite-in-calcite geothermometer of Rice (1977) on calcite rims of magnesian borates that are apparently in equilibrium with dolomite are $294-574^{\circ} \mathrm{C}$ for magnesite contents of 0.65-6.30 mol\% (Marincea, 1998). They are in very good agreement with temperatures of experimental synthesis of $\mathrm{Fe}$-poor szaibelyite, kotoite and of $\mathrm{Al}$ and Ti-depleted ludwigite $\left(300-600^{\circ} \mathrm{C}\right)$, which accounts for the crystallization of borates by metasomatic replacement of dolomite.

\section{REFERENCES}

Aleksandrov, S.M. 1982. Geochemistry of boron and tin in magnesian skarn deposits. Nauka Ed., Moscow, 272 pp. (in Russian).

BASTA, E.Z. 1957. Accurate determination of the cell dimensions of magnetite. Mineral. Mag., 31, 431-442.

Berza, T.; Constantinescu, E.; Vlad, S.N. 1998. Upper Cretaceous magmatic series and associated mineralisation in the CarpathianBalkan Orogen. Resource Geology, 48: 291-306.

Hârtopanu, I.; Hârtopanu, P.; Balintoni, I.; Borcos, M.; LuPU, M.; Rusu, A. 1982. Geological Map of Romania, 1:50000. Valea Ierii sheet. Explanatory note. Geological Survey of Romania (ed.), Bucharest.

Iancu, V.; Balintoni, I. 1986. The mineral assemblages and parageneses in the metamorphics of the Baia de Aries Group, Apuseni Mountains. In: Mineral parageneses. Theophrastus Publications, 473-493, Athens.

JaHAnBagloo, I.C. 1969. X-ray diffraction study of olivine solid solution series. Amer. Mineral., 54: 246-250.

JANkovic, S. 1997. The Carpatho-Balkanides and adjacent area: a sector of the Tethyan Eurasian metallogenetic belt. Mineralium Deposita, 32: 426-433.

MarinceA, S. 1997. Kotoite in Romania: A third occurrence (Cacova Ierii, Gilau Mountains) and review. Roman. J. Mineral. 78 (Suppl. 1): 52-53.

MarinceA, S. 1998. Cristallochimie et propriétés physiques des borates magnésiens des skarns de la province banatitique de Roumanie. Ph.D. thesis, Ecole Nationale Supérieure des Mines de Saint-Etienne, France, 469 pp.

MarinCEA, S.; CRISTEA, C. 1995. Ludwigite, szaibelyite and pyroaurite at Cacova Ierii (Gilau Mountains): New occurrences in the Banatitic Province in Romania. Roman. J. Mineral., 76: 67-84.

Pertsev, N.N. 1991. Magnesian skarns. In: Skarns: their genesis and metallogeny. Theophrastus Publications, p. 299-324, Athens.

Popov. P.; Berza, T.; Grubic, A. 2000. Upper Cretaceous ApuseniBanat-Timok-Srednogorie (ABTS) magmatic and metallogenetic Belt in the Carpathian-Balkan Orogen. ABCD-GEODE 2000 Workshop - Borovets, Bulgaria, Abstracts Volume, 69-70.

Rice, J.M. 1977. Progressive metamorphism of impure dolomitic limestone in the Marysville aureole, Montana.Amer. J. Sci. 277: $1-24$.

Stefan, A.; Lazar, C.; Berbeleac, I.; Udubasa, G. 1988. Evolution of the Banatitic magmatism in the Apuseni Mountains and the associated metallogenesis. D. S. Inst. Geol. Geofiz., 72/73 (2): 195-213.

von CotTA, B. (1864): Erzlagerstätten im Banat und in Serbien. W. Braumüller Ed., Wien, 105 pp. 